\title{
Sistem Informasi Rekam Medis Pasien Umum Dan Covid-19 Pada Klinik Dr. Mulio Soreang
}

\author{
Triska Puspita Rahayu*1, Velika Rohmana Putri ${ }^{2}$, Falaah Abdussalaam ${ }^{3}$ \\ ${ }^{1,2}$ Jurusan Informatika Rekam Medis, Program Studi Manajemen Informatika \\ ${ }^{3}$ Dosen Program Studi Manajemen Informatika \\ Politeknik Piksi Ganesha, Jl. Gatot Subroto No.301, Maleer, Kec. Batununggal, Kota Bandung, \\ Jawa Barat 40274, Tlp (022) 87340030 \\ e-mail: piksi.triskapr.18403056@gmail.com*1, velikarohmanaputri@gmail.com², \\ falaah_abdussalaam@yahoo.com ${ }^{3}$
}

\begin{abstract}
Abstrak
Pada era digitalisasi dan apalagi pada masa pandemik Covid-19 ini pencatatan yang efisien dan aman lebih ditekankan. Ketika instruksi manual bisa diganti dengan sistem elektronik. Salah satu contoh adalah pencatatan rekam medis pada Klinik dr. Mulio Soreang yang dirasa kurang efisien, karena masih menggunakan cara manual. Cara manual membutuhkan banyak waktu dan tenaga, rawan terjadi human error, mengurangi kualitas berkas rekam medis, dan tidak sesuai dengan kondisi pandemik. Sehingga, pelayanan kesehatan bagi pasien menjadi tidak optimal dan menurunkan kualitas kerja petugas. Maka, dibutuhkan sebuah sistem informasi rekam medis baru sebagai solusi untuk permasalahan tersebut. Perancangan sistem informasi ini menggunakan metode System Development Life Cycle (SDLC) waterfall. Hasil dari penelitian ini berupa sistem informasi yang diberi nama SIRCoVIT Klinik dr. Mulio Soreang yaitu aplikasi yang dapat membantu proses input data pasien umum dan Covid-19, pendokumentasian rekam medis pasien, dan pelaporan. Aplikasi ini dibuat dengan menggunakan bahasa pemrograman PHP dan Database yang digunakan adalah MySQL. Sedangkan, teks editor yang digunakan adalah Visual Studio Code dan Bootstrap dipilih sebagai framework.
\end{abstract}

Kata Kunci: Sistem Informasi Rekam Medis, PHP, MySQL, Visual Studio Code, Bootstrap.

\begin{abstract}
In the era of digitalization and especially during the Covid-19 pandemic, efficient and safe recording is emphasized. When the instruction manual can be replaced with an electronic system. One example is the recording of medical records at the Clinic dr. Mulio Soreang which is considered less efficient, because it still uses the manual method. The manual method requires a lot of time and effort, is prone to human error, reduces the quality of medical record files, and is not in accordance with pandemic conditions. Thus, health services for patients are not optimal and reduce the quality of work of officers. So, a new medical record information system is needed as a solution to this problem. The design of this information system uses themethod System Development Life Cycle (SDLC) Waterfall. The result of this research is an information system named SIRCoVIT Clinic dr. Mulio Soreang is an application that can assist in the process of inputting general and Covid-19 patient data, documenting patient medical records, and reporting. This application is made using the PHP programming language and the database used is MySQL. Meanwhile, the text editor used was Visual Studio Code and Bootstrap was chosen as the framework.
\end{abstract}

Keywords: Medical Record Information System, PHP, MySQL, Visual Studio Code, Bootstrap. 


\section{PENDAHULUAN}

Dunia sedang berperang menghadapi pandemik bernama Covid-19. Pada bulan Desember tahun 2019 di Tiongkok, Wuhan ditemukan sebuah virus baru yaitu virus SARS CoV-2 (Virus Corona) yang merupakan penyebab penyakit Covid-19. Virus tersebut ditularkan oleh hewan ke manusia dan manusia ke manusia pada saat batuk/bersin (droplet). Orang yang beresiko tinggi terlular Covid-19 adalah orang yang kontak erat dengan penyintas Covid-19. Penambahan jumlah kasus positif belangsung cepat, diantara kasus tersebut termasuk tenaga kesehatan yang dilaporkan terinfeksi [1]. Berbagai sistem informasi pada fasilitas pelayanan kesehatan dituntut untuk mampu bersaing dengan peningkatan kebutuhan akan pelayanan kesehatan bagi pasien Covid-19, yang diperburuk oleh rasa takut, disinformasi, dan pembatasan pergerakan yang menghambat proses pemberian pelayanan kesehatan bagi penyakit lain [2], salah satunya berdampak pada bagian rekam medis. Rekam medis adalah berkas berisi catatan dan dokumen tentang pasien yang berisi identitas, pemeriksaan, pengobatan, tindakan medis lain pada sarana pelayanan kesehatan untuk rawat jalan dan inap baik dikelola pemerintah maupun swasta [3]. Sedangkan, Sistem Informasi yaitu sistem yang menyediakan informasi bagi manajemen untuk mengambil keputusan dan menjalankan operasional perusahaan sebagai kombinasi dari orangorang, teknologi informasi, dan prosedur-prosedur yang terorganisasi. Ciri-ciri sistem yaitu terdapat komponen-komponen, terintegrasi (saling berhubungan), adanya batasan sistem, memiliki tujuan yang jelas, mempunyai lingkungan (environment), terdiri dari input, proses, dan output [4].

Pada era digitalisasi dan apalagi pada masa pandemik Covid-19 ini pencatatan yang efisien lebih ditekankan. Ketika instruksi manual dapat diganti dengan sistem elektronik. Sebuah perangkat lunak sistem berbasis data pasien akan bermanfaat bagi fasilitas pelayanan kesehatan agar data dapat diakses dengan cepat, aman, dan akurat [5].

Salah satu contoh adalah pencatatan rekam medis pada Klinik dr. Mulio Soreang yang dirasa kurang efisien, karena masih menggunakan cara manual. Seringkali ditemui kesalahan terkait human error dalam praktiknya, sehingga mengurangi kualitas rekam medis dan menghambat proses pelayanan kesehatan bagi pasien. Maka, perlu dirancang sebuah sistem baru yang sesuai dengan kondisi saat ini. Perancangan merupakan kegiatan dengan tujuan membuat sistem baru yang terstruktur, sehingga mampu menghasilkan sistem yang diharapkan [6]. Tujuan dari penelitian ini adalah untuk merancang sistem informasi rekam medis pasien umum dan Covid-19 guna meningkatkan efektifitas dan efisiensi kerja dalam upaya memberikan pelayanan kesehatan yang optimal.

\section{METODE PENELITIAN}

Data yang digunakan adalah data primer yaitu, data mentah yang diambil secara langsung dari dokumen rekam medis, buku registrasi pasien laki-laki dan perempuan, dan file data pasien pada software Microsoft Excel di unit rekam medis Klinik dr. Mulio Soreang. Data tersebut diperoleh menggunakan teknik pengumpulan data observasi partisipatif selama dua bulan, dokumentasi berkas dan alur rekam medis, dan wawancara mendalam dengan beberapa pasien yang dipilih secara acak, petugas rekam medis, dan dokter sekaligus pemilik dari Klinik dr. Mulio Soreang.

Data yang terkumpul dianalisis untuk mencari permasalahan pada sistem berjalan, kemudian data diolah untuk dijadikan dasar perancangan sistem informasi rekam medis baru sebagai solusi penyelesaian masalah.

1. Observasi Partisipatif

Observasi partisipatif peneliti mengamati, mendengarkan, dan ikut serta dalam aktifitas yang dilakukan oleh objek yang sedang diteliti [7].

\footnotetext{
Rahayu, et., al [Sistem Informasi Rekam Medis Pasien Umum dan Covid-19 pada Klinik Dr. Mulio Soreang]
} 
2. Wawancara

Wawancara adalah pertemuan yang dilakukan oleh dua orang untuk bertukar informasi maupun ide dengan cara tanya jawab, sehingga dapat dikerucutkan menjadi sebuah kesimpulan atau makna dalam topik tertentu [8].

Metode perancangan perangkat lunak yang digunakan yaitu metode System Development Life Cycle (SDLC) waterfall yaitu proses mengembangkan atau mengubah suatu sistem perangkat lunak dengan menggunakan metodologi berdasarkan cara-cara yang sudah teruji baik [9]. Tahapan-tahapan SDLC yaitu requierements analysis (analisis kebutuhan), system design (desain sistem), implementation (pengerjaan), integration and system testing, operation and maintenance (pengoprasian dan pemeliharaan) (Lihat Gambar 1) [10].

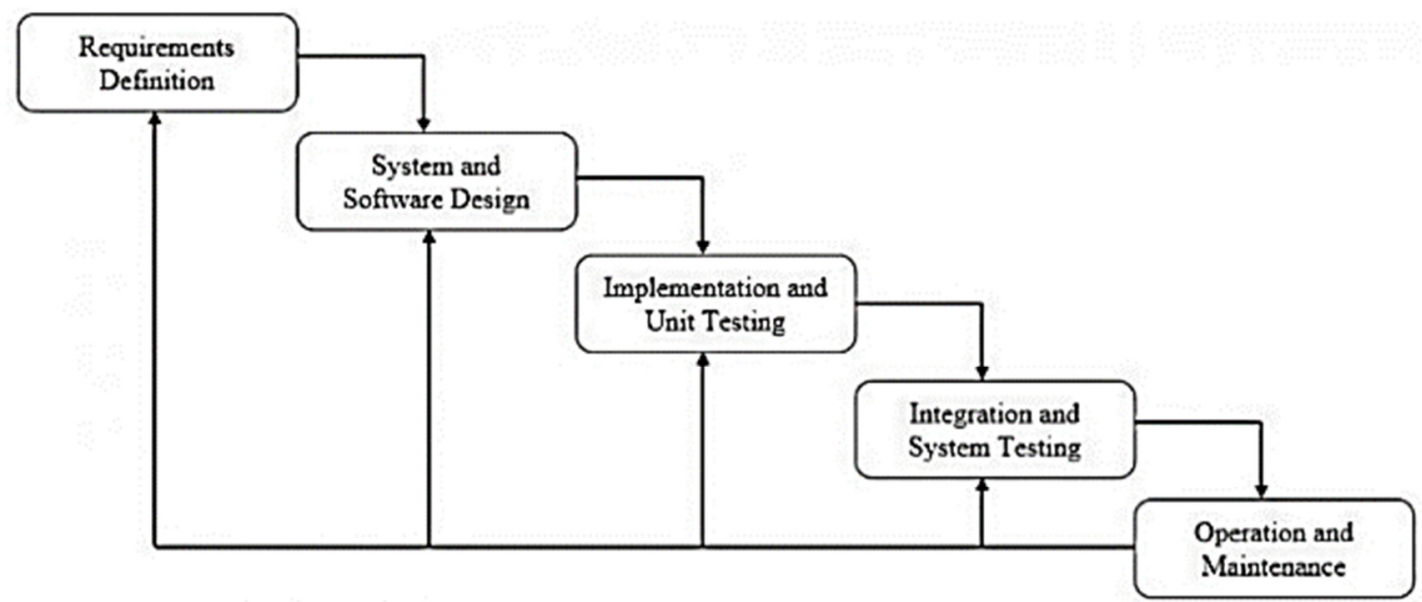

Gambar 1. Metode System Development Life Cycle Waterfall

(Sumber: dosenit.com)

1. Requierements Definition (Analisis Kebutuhan)

Dalam tahap ini peneliti mengumpulkan data kebutuhan pengguna terhadap sebuah perangkat lunak yang dilakukan melalui observasi partisipatif dan wawancara mendalam kepada objek, sehingga peneliti mampu memahami bisnis konten, kebutuhan output, dan fitur yang dibutuhkan oleh objek.

2. System and Software Design (Desain Sistem dan Perangkat Lunak)

UML (Unified Modeling language) adalah model penggambaran sistem yang dipilih pada penelitian ini berupa Use Case diagram dan Class diagram.

3. Implementation and Unit testing (Pengerjaan)

Pada tahap ini dibangun sebuah sistem informasi rekam medis berdasarkan pada desain yang sudah ditentukan pada tahap sebelumnya. Bahasa pemrograman yang digunakan adalah PHP dan Database yang dipilih yaitu MySQL, teks editor Visual Studio Code, framework Bootstrap dan Laravel. Sedangkan web server yang dipakai yaitu XAMPP (Apache, MySQL).

Pengujian unit dilakukan untuk memastikan setiap unit dibuat sesuai dengan rancangan spesifikasi sistem dan setiap fungsi kebutuhan berjalan dengan baik.

4. Integration and System Testing

Setiap bagian unit sistem yang sudah dibangun kemudian di uji secara keseluruhan sebagai suatu sistem yang utuh untuk memastikan bahwa sistem dapat dipergunakan dengan baik oleh petugas rekam medis. 
5. Operation and Maintenance (Pengoprasian dan Pemeliharaan).

Proses perbaikan dan pengembangan sistem lebih lanjut dilakukan pada tahap ini, jika dirasa masih terdapat beberapa kekurangan atau adanya kebutuhan lain pada sistem yang telat dibuat.

\section{HASIL DAN PEMBAHASAN}

\section{Analisis Sistem Berjalan}

Klinik dr. Mulio Soreang didirikan pada tahun 2015 oleh dr. Erwin Muliono yang bertujuan untuk memberikan layanan kesehatan pertama pada masyarakat [11], khususnya masyarakat di daerah Soreang. Alur rekam medis diawali dengan proses pendaftaran. Pencatatan identitas pasien dilakukan secara manual oleh seorang petugas non rekam medis pada Kartu Indeks Utama Pasien (KIUP), lalu data dicatat ke dalam buku registrasi pasien untuk menentukan nomor rekam medisnya secara alfabetis berdasarkan jenis kelamin, kemudian dibuat Kartu Indentitas Berobat (KIB) untuk diserahkan kepada pasien. Selanjutnya dilakukan pemeriksaan oleh dokter, kemudian baru dilakukan pencatatan secara komputerisasi menggunakan software Microsoft Excel. Namun, data yang diinput hanya identitas pasien dan nomor rekam medisnya saja, sedangkan isi rekam medis seperti anamesa, diagnosa, tindakan dan terapi obat oleh dokter dicatat secara manual ke dalam buku besar.

Disimpulkan bahwa masalah pada sistem tersebut diantaranya salah ketik identitas pasien, buku registrasi pasien laki-laki dan pasien perempuan tertukar, penggandaan nomor rekam medis, salah penomoran, data pasien tidak up to date, dan sulit dalam membuat pelaporan apalagi di masa pandemik Covid-19 ini dimana klinik masih menjadi harapan masyarakat untuk mendapat pelayan kesehatan karena keterbatasan fasilitas yang tersedia di Puskesmas dan Rumah Sakit.

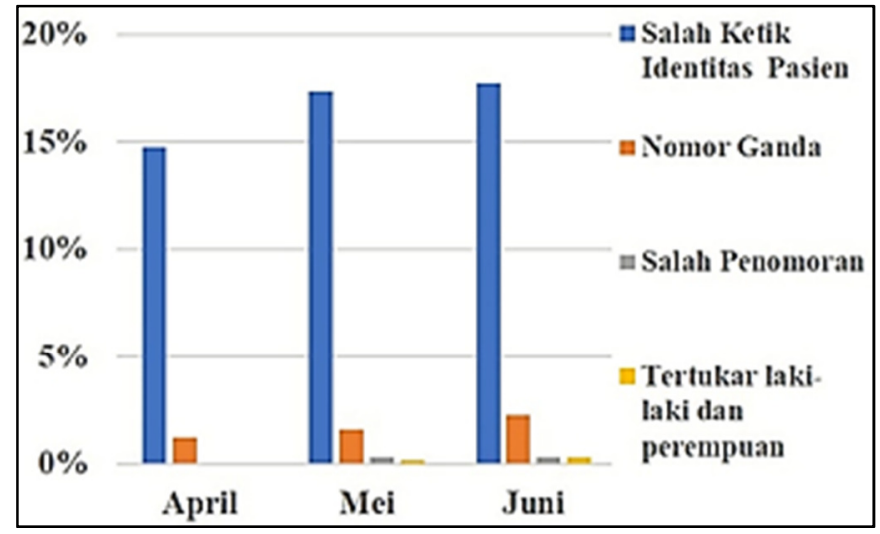

Gambar 2 Kesalahan Input Data Pasien Baru di Klinik Dr. Mulio Soreang Periode Bulan April-Juni 2021, Diambil dari Buku Registrasi Pasien dan File Data Pasien.

Sistem baru yang diusulkan oleh peneliti diberi nama SIRCoVIT (Sistem Informasi Rekam medis dan CoVId-19 Things) Klinik dr. Mulio Soreang, yaitu sebuah sistem informasi berbasis web. Penggambaran perancangan sistem dibuat menggunakan Use Case diagram dan Class diagram. 
1. Use Case Diagram

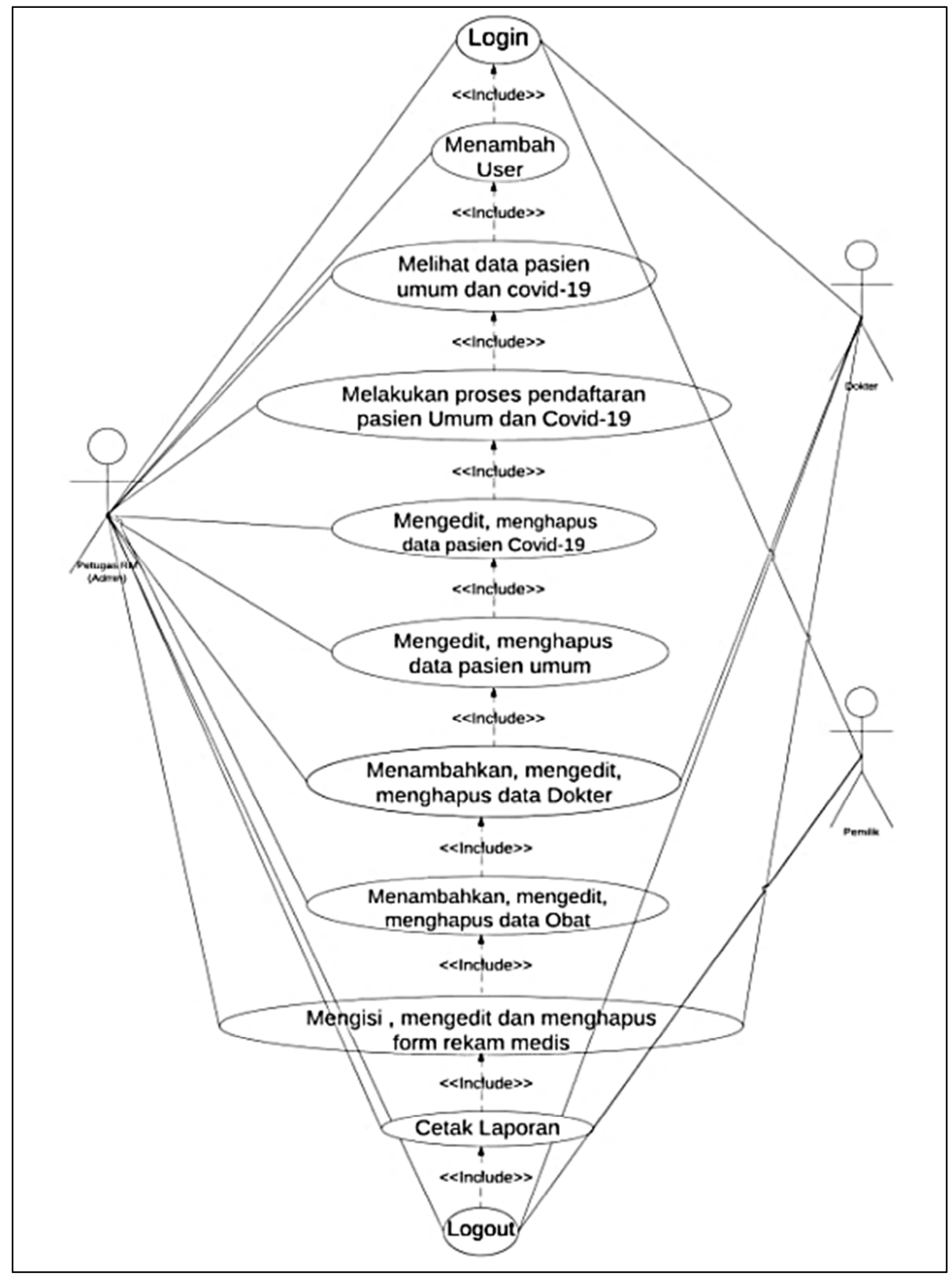

Gambar 3. Use Case Diagram 


\section{Class Diagram}

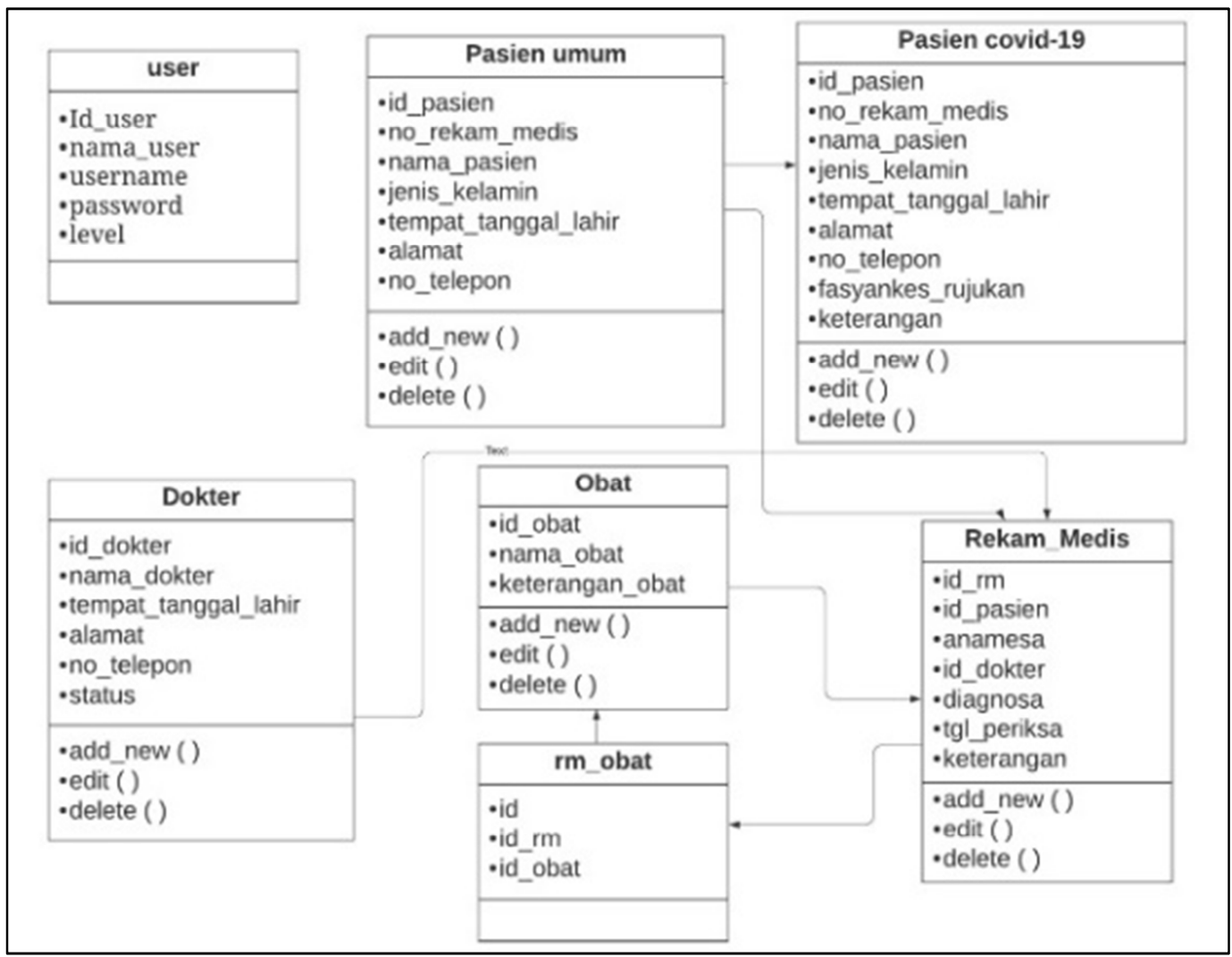

Gambar 4 Class Diagram

3. Implementasi Antar Muka (Interface)

a. Menu Login

Merupakan halaman tempat setiap user melakukan proses Login untuk bisa masuk ke akun masing-masing.

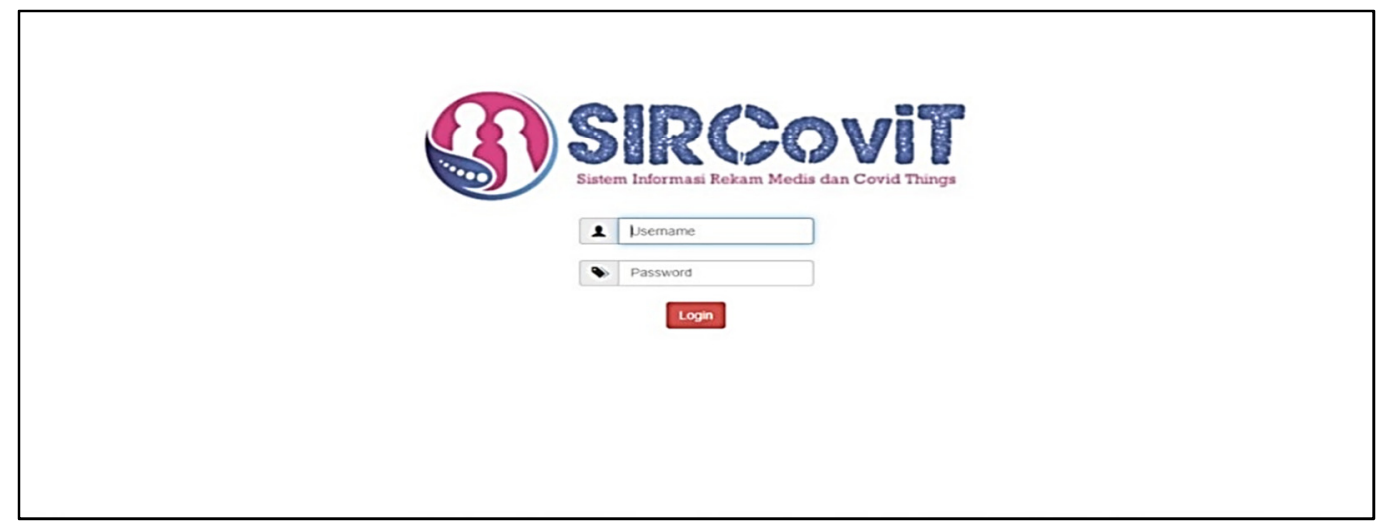

Gambar 5. Tampilan Awal Menu Login

b. Halaman Utama (Dashboard)

Rahayu, et., al [Sistem Informasi Rekam Medis Pasien Umum dan Covid-19 pada Klinik Dr. Mulio Soreang] 
Halaman utama menampilkan semua pilihan menu pada aplikasi SIRCoVIT Klinik dr. Mulio Soreang.

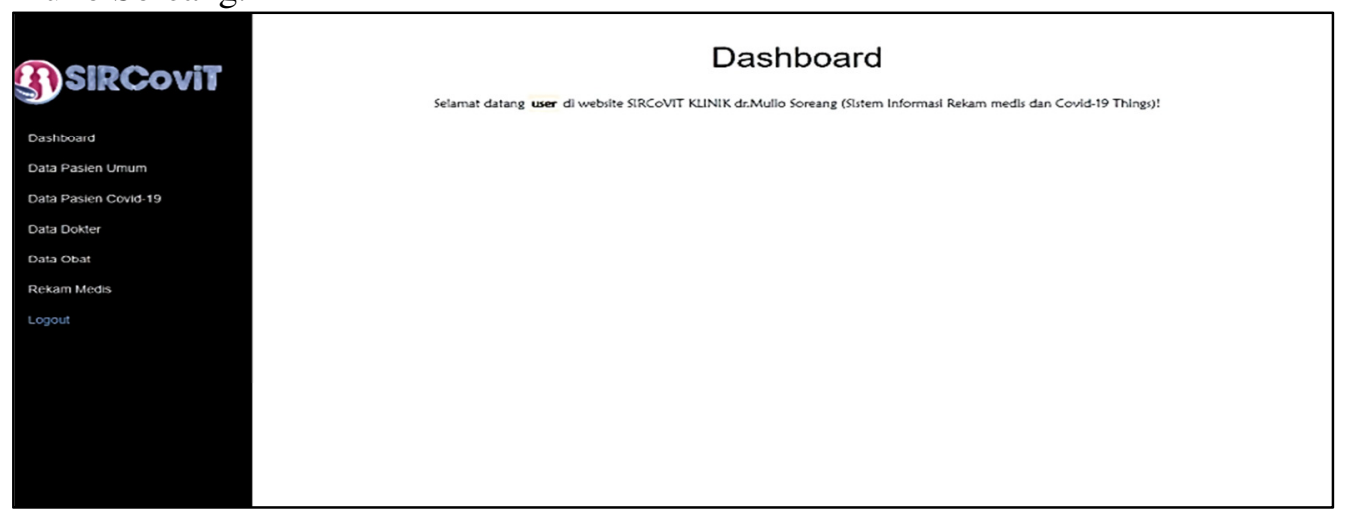

Gambar 6. Tampilan Halaman Utama

c. Menu Data Pasien Umum

Pada halaman ini petugas rekam medis dapat melihat data pasien umum, menambah data pasien (proses pendaftaran pasien baru), mengedit data jika terjadi salah input, dan menghapus data. Terdapat pula fitur cetak laporan dengan berbagai format file untuk pemilik.

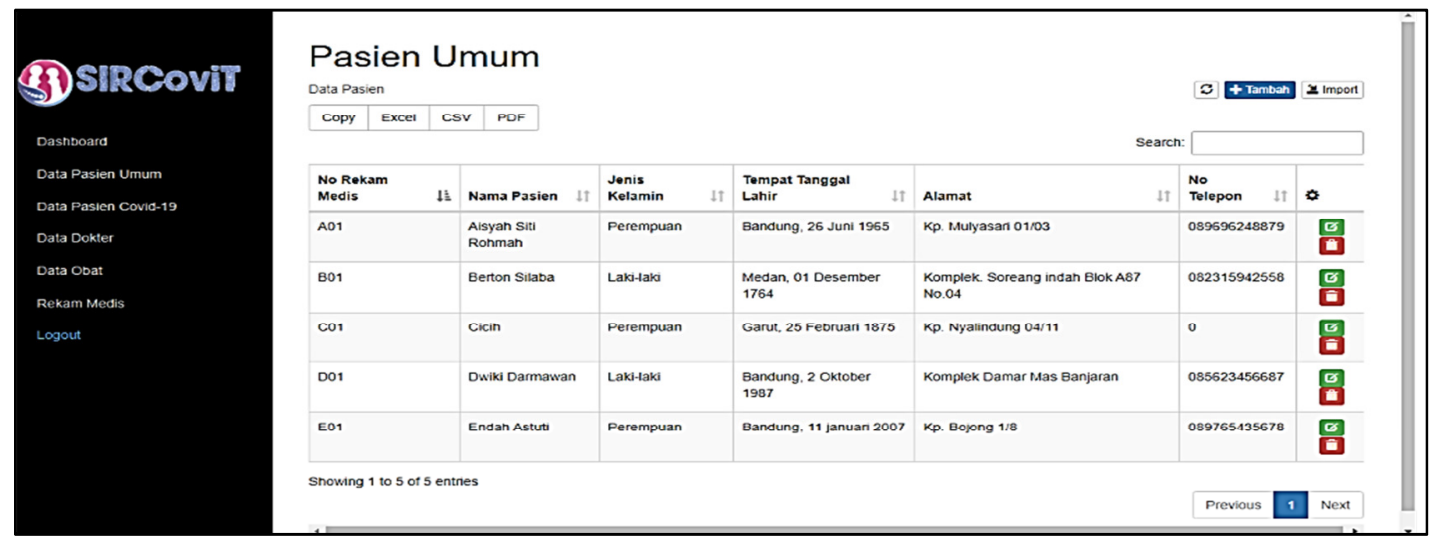

Gambar 7. Tampilan Menu Data Pasien Umum

\section{d. Menu Data Pasien Covid-19}

Petugas rekam medis menginput ulang data dari data pasien umum jika pasien tersebut didiagnosis positif Covid-19, mengedit data jika ditemukan salah input data pasien, dan menghapus data. Terdapat fitur cetak laporan untuk pemilik seperti pada halaman menu data pasien umum. 


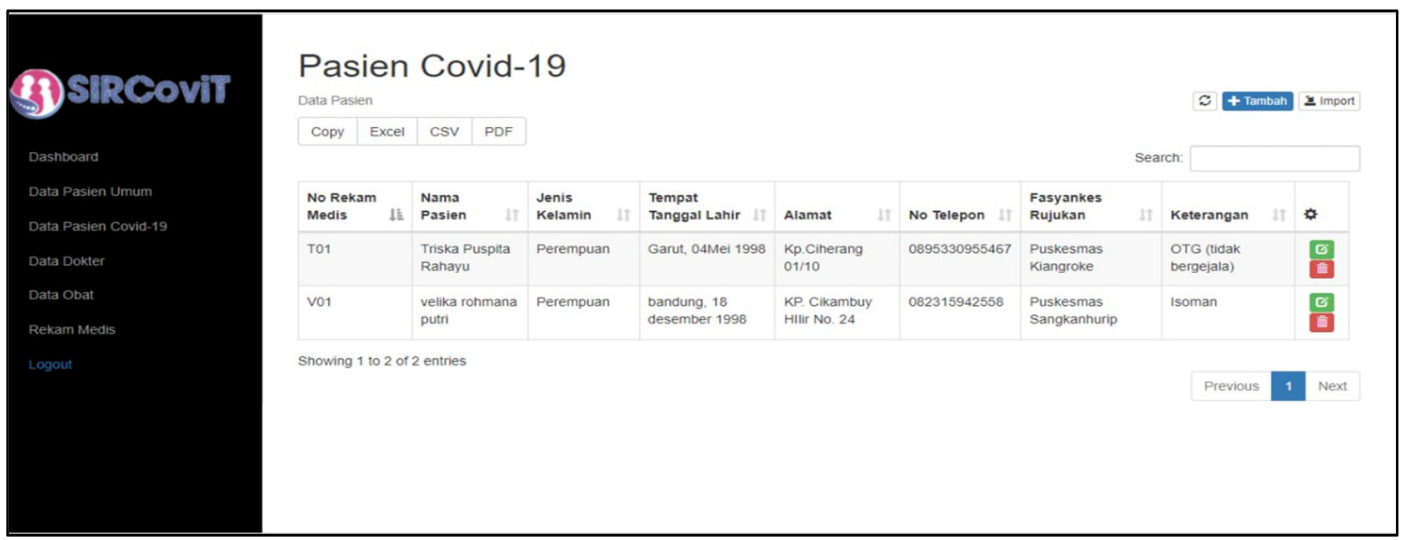

Gambar 8. Tampilan Menu Data Pasien Covid-19

e. Menu Data Dokter

Petugas rekam medis dan dokter dapat melihat, menambah, mengedit, dan menghapus data dokter.

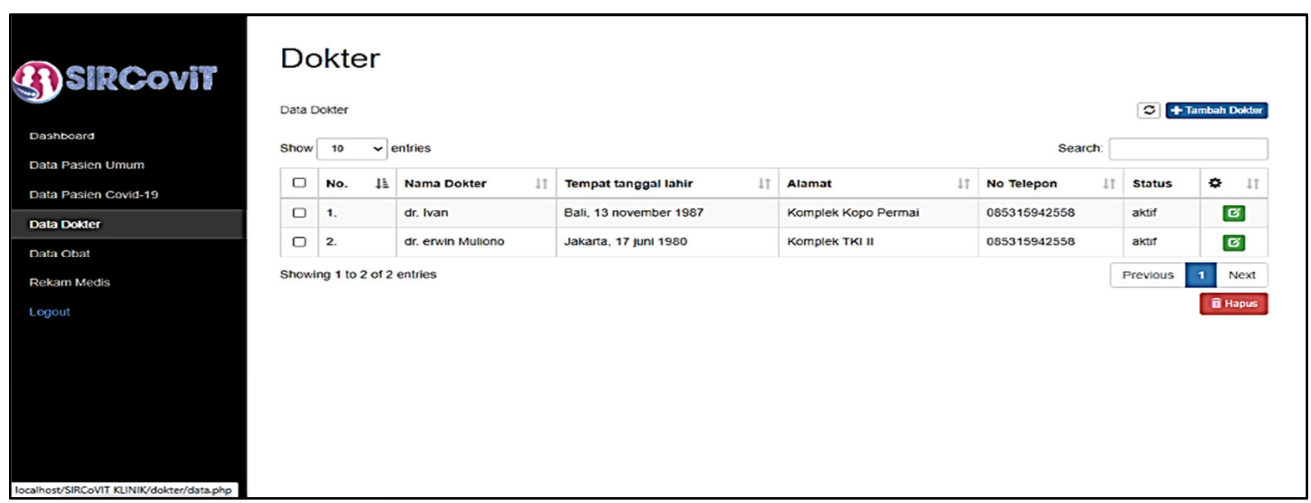

Gambar 9. Tampilan Menu Data Dokter

f. Menu Data Obat

Petugas rekam medis dapat melihat, menambah, mengedit, dan menghapus data obat sesuai dengan kebutuhan. Halaman ini diperuntukan untuk mengisi data obat di bagian rekam medis. 


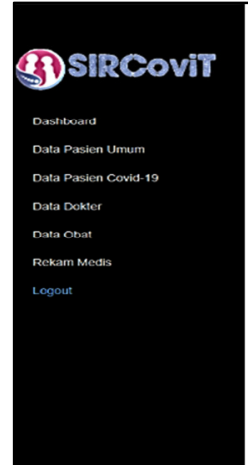

\section{Obat}

Tambarn Dota c caat

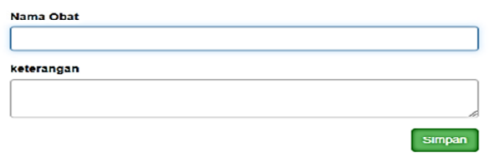

SKemball

Gambar 10 .Tampilan Menu Data Obat

g. Menu Rekam Medis

Petugas rekam medis dan dokter berwenang untuk menginput data rekam medis diantaranya data identitas pasien, tanggal pemeriksaan, anamesa, diagnosa, terapi obat, dan keterangan penunjang pemeriksaan.

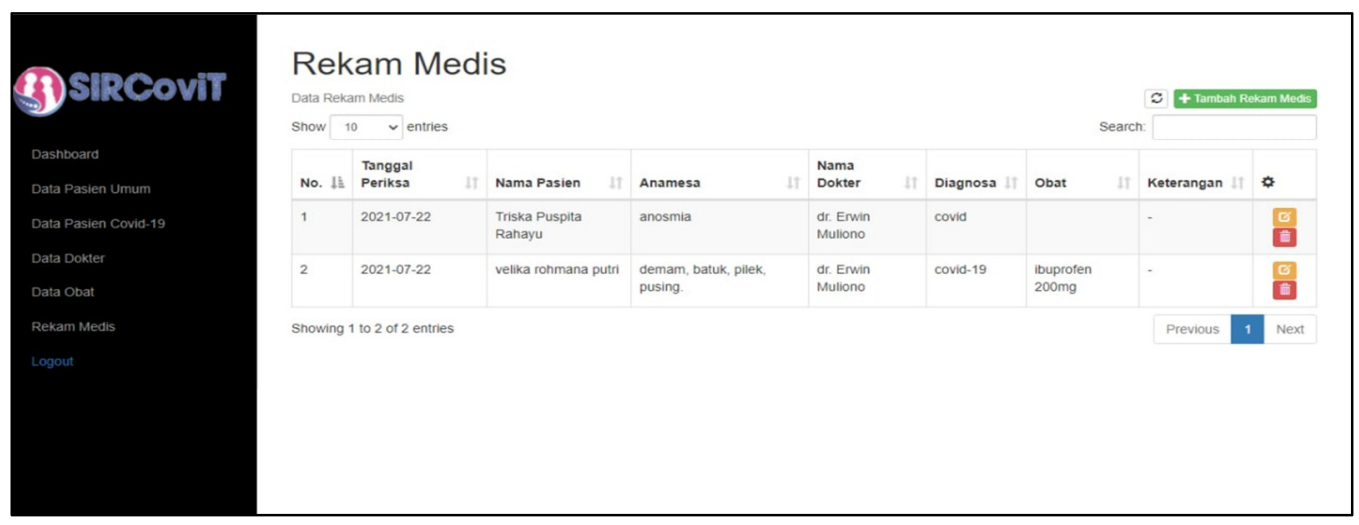

Gambar 11. Tampilan Menu Rekam Medis

h. Laporan yang dicetak

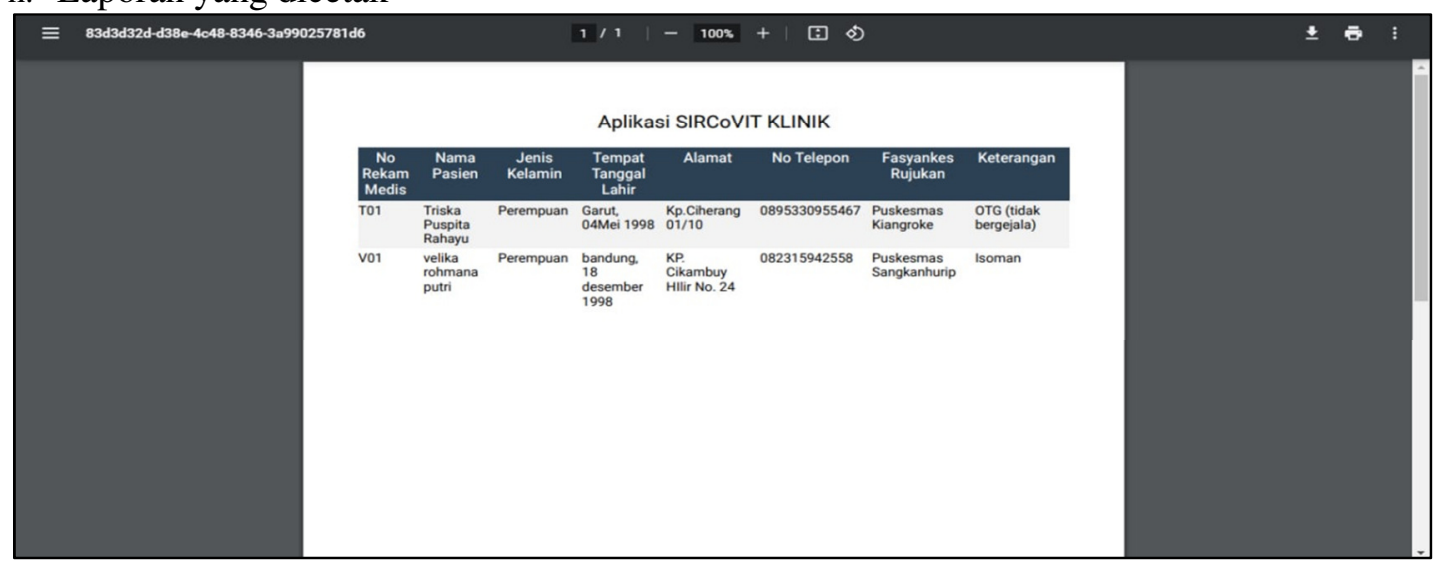

Gambar 12. Tampilan Menu Laporan Pasien Covid-19 Format PDF 


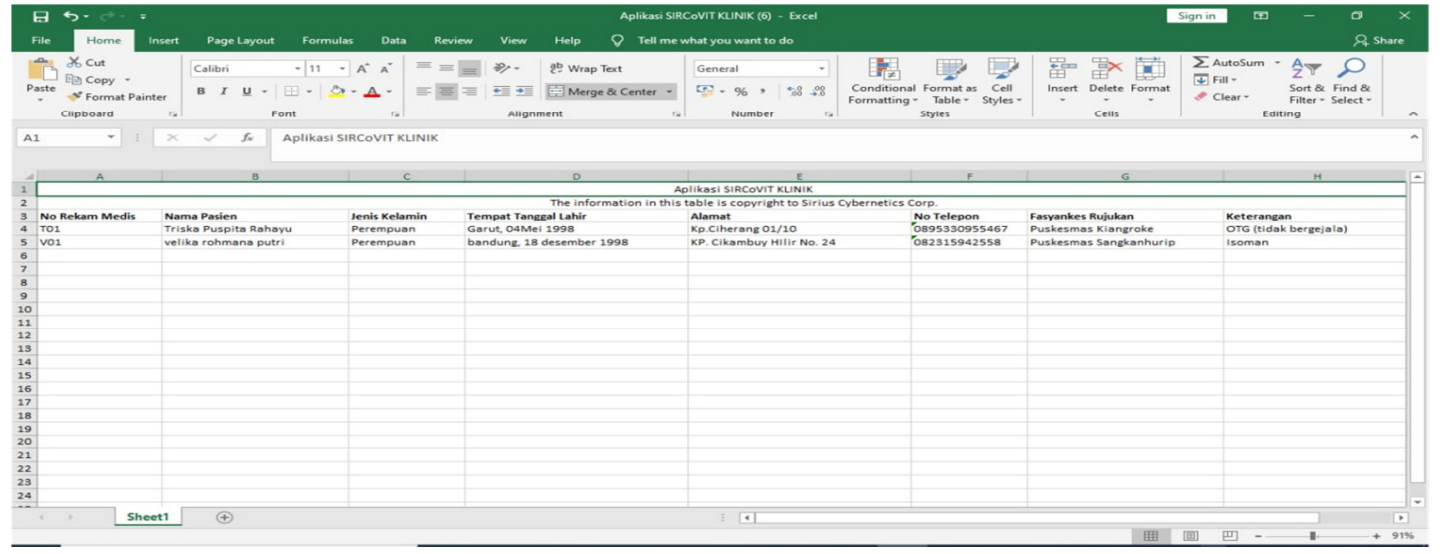

Gambar 13. Tampilan Menu Laporan Pasien Covid-19 Format Microsoft Excel

i. Menu Logout

User keluar dari aplikasi.

\section{KESIMPULAN}

SIRCoVIT Klinik dr.Mulio dibangun dengan tujuan untuk mempermudah penyelenggaraan pelayanan kesehatan di unit rekam medis. Dalam sistem ini terdapat 11 kebutuhan fungsional dengan 3 aktor utama (User) yaitu, Admin Petugas Rekam Medis, Dokter, dan Pemilik. Perancangan digambarkan dengan UML berupa Use Case diagram dan Class diagram. Sistem dibangun berbasis web secara sederhana menggunakan bahasa pemrograman PHP, dengan MySQL sebagai Database. Setelah diuji coba SIRCoVIT dirasa lebih efisien dibanding sistem sebelumnya (manual).

\section{SARAN}

Sistem Informasi Rekam Medis yang peneliti buat masih dapat dikembangkan menjadi lebih baik, karena sistem ini dibuat dengan keterbatasan peralatan dan data yang tersedia. Seperti penambahan fitur-fitur penunjang kebutuhan pelayanan kesehetan lainnya, tampilan yang lebih menarik, dan fungsi yang lebih kompleks disesuaikan dengan kebutuhan klinik di masa yang akan datang.

\section{UCAPAN TERIMAKASIH}

Peneliti mengucapkan terimakasih kepada Klinik dr. Mulio Soreang yang telah berkenan memberikan izin untuk melakukan observasi selama dua bulan. Terimakasih kepada Politeknik Piksi Ganesha Bandung serta dosen pembimbing yang telah membantu peneliti dalam mengerjakan observasi. Dan terimakasih kepada keluarga, teman serta kerabat yang telah memberikan dukungan baik materi maupun non materi kepada peneliti sehingga sistem informasi rekam medis ini dapat peneliti selesaikan dengan baik. 


\section{DAFTAR PUSTAKA}

[1] R. N. Putri, 2020, "Indonesia Dalam Menghadapi Pandemi Covid-19," J. Ilm. Univ. Batanghari Jambi, Vol. 20, No. 2, p. 705, doi: 10.33087/jiubj.v20i2.1010.

[2] World Health Organization, 2020, "Mempertahankan Layanan Kesehatan Esensial: Panduan Operasional Untuk Konteks COVID-19," Pandu. Interim, [Online]. Available: https://www.who.int/docs/default-source/searo/indonesia/covid19/maintaining-essentialhealth-services---ind.pdf?sfvrsn=d8bbc480_2.

[3] N. 26. Permenkes, 2008. "Permenkes No. 269/Menkes/Per/III/2008:Rekam Medis.” p. 7,

[4] A. Novega Pratama, 2020. Dasar-dasar Teknik Informatika - Google Books. Yogyakarta,

[5] H. Rohman, 2019, "Sistem Retensi Berkas Rekam Medis Terintegrasi: Perancangan Sistem Informasi Berbasis Web di Klinik Pratama," J. Manaj. Inf. dan Adm. Kesehat., Vol. 2, Dec. doi: 10.32585/jmiak.v2i02.452.

[6] Sugianto, 2015, Metode Penelitian Manajemen. Bandung: Alfabeta.

[7] E. W. Winarmi and R. A. Kusumaningtyas, 2018, Teori dan Praktek Penelitian Kuantitatif Kualitatif. Jakarta: Bumi Aksara.

[8] M. Muchson, 2017, Statistik Deskriptif, Guepedia, Bogor.

[9] S. M and Rosa, 2015, Rekayasa Perangkat Lunak Terstruktur dan Berorientasi Objek. Informatika, Bandung.

[10] I. Sommerville, 2011, Software engineering (Rekayasa Perangkat). Erlangga, Jakarta,.

[11] Departemen Kesehatan RI, 2014, "Peraturan Menteri Kesehatan Republik Indonesia Nomor 9 Tahun 2014 Tentang Klinik," in Menteri Kesehatan Republik Indonesia Peraturan Menteri Kesehatan Republik Indonesia, Vol. 65, No. 879, pp. 2004-2006. 